\section{Commentary: Form improves function: The importance of a well-constructed neoaortic arch}

\author{
Mohan J. John, MD, and Travis J. Wilder, MD
}

The importance of a well-constructed neoaortic arch during a Norwood procedure is not just because it is aesthetically pleasing. According to Schafer and colleagues, ${ }^{1}$ wellconstructed neoaortic aortic arch may have long-term hemodynamic implications for children with hypoplastic left heart syndrome (HLHS) and related variants requiring single-ventricle palliation. ${ }^{1}$

Survival among neonates with HLHS has dramatically improved since the Norwood operation was first reported in $1983 .{ }^{2}$ Hospital survival that was reported around $52 \%-68 \%$ in early studies has improved to between $80 \%$ and $85 \%{ }^{3}$. Furthermore, the 10 -year survival published in reports from 2000 to 2005 was $40 \%$ to $50 \%$ compared with contemporary survival reported to be between $60 \%$ and $70 \% .^{3-5}$ With the expectation that many patients with HLHS will live into their second and third decade of life-perhaps longer-clinicians are focused on improving the long-term durability of the right ventricle when subjected to single-ventricle physiology.

The Fontan circulation is associated with nonpulsatile pulmonary blood flow, chronic systemic venous hypertension, and low cardiac output. ${ }^{6}$ Although many of the complications associated with single-ventricle physiology are a result of these hemodynamic derangements (ie, plastic bronchitis and protein-losing enteropathy), over time, all patients with HLHS will eventually develop heart failure. ${ }^{7,8}$

\footnotetext{
From the Division of Congenital Heart Surgery, Texas Children's Hospital, Baylor College of Medicine, Houston, Tex.

Disclosures: The authors reported no conflicts of interest.

The Journal policy requires editors and reviewers to disclose conflicts of interest and to decline handling or reviewing manuscripts for which they may have a conflict of interest. The editors and reviewers of this article have no conflicts of interest.

Received for publication March 5, 2021; revisions received March 5, 2021; accepted for publication March 5, 2021; available ahead of print March 10, 2021.

Address for reprints: Travis J. Wilder, MD, Division of Congenital Heart Surgery, Texas Children's Hospital, Baylor College of Medicine, Legacy Tower, Floor 19, 6651 Main St, Mail Code 19345H, Houston, TX 77030 (E-mail: tjwilder@ texaschildrens.org).

J Thorac Cardiovasc Surg 2021;162:1807-8

$0022-5223 / \$ 36.00$

Copyright (c) 2021 by The American Association for Thoracic Surgery

https://doi.org/10.1016/j.jtcvs.2021.03.019
}

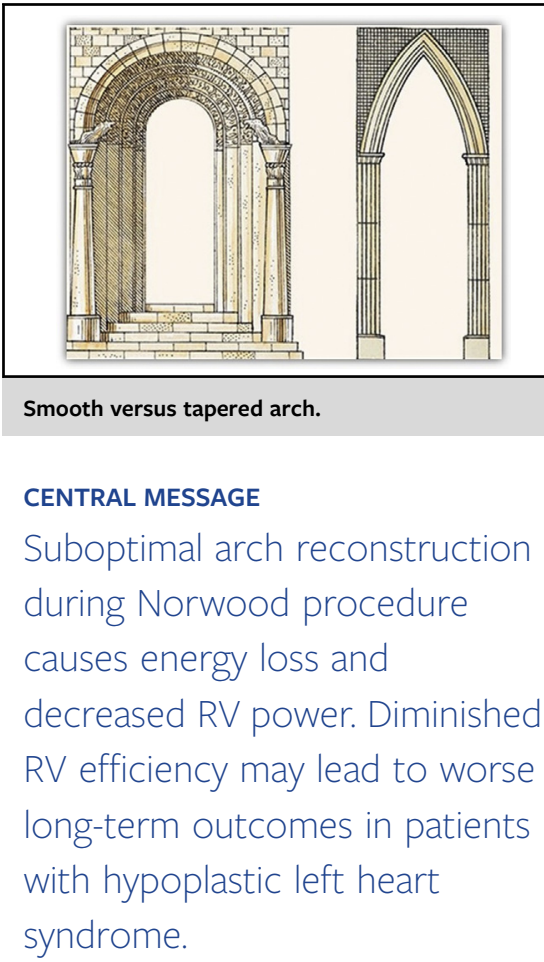

Although it is somewhat intuitive to expect a systemic right ventricle to fail, improved mechanical efficiency of the systemic and pulmonary circulations may delay the onset of cardiac failure after single-ventricle palliation. ${ }^{9}$

Given the importance of optimizing cardiac efficiency after single-ventricle palliation, Schafer and colleagues ${ }^{1}$ set out to identify the association between neoaortic arch geometry and flow-related viscous energy loss $\left(E_{L}\right)$. Specifically, they used state-of-the-art, 4-dimensional magnetic resonance imaging to characterize dynamic aortic flow patterns in patients after Norwood palliation. They went on to classify the degree of neoaortic tapering (ie, variation of aortic size along its length) and aortic morphology in an effort to determine the relationship between arch geometry and $E_{L}$. Further, they investigated the effect of flow-related mechanical $E_{L}$ on right ventricle power. Thus, the study indirectly links the quality of neoaortic reconstruction with cardiac efficiency of the single right ventricle.

The study included 26 patients with HLHS after stage- 1 Norwood procedure. The stage of palliation was varied and included 5 patients in the post-Norwood/pre-Glenn interstage period, 12 patients after cavopulmonary shunt, and 
9 patients post-Fontan. A median aortic tapering value (defined as the standard deviation of aortic diameter measured at 4 prespecified locations along the aorta) was calculated for all patients. A median value of $0.52 \mathrm{~cm}$ was considered the cutoff between a high degree of tapering (Group H) and low degree of tapering (Group L). Key findings showed that patients in Group $\mathrm{H}$ demonstrated increased flow related $E_{L}$ in all measured aortic regions. The study also showed that patients in Group $\mathrm{H}$ were susceptible to increased right ventricle power loss compared with Group L. Finally, they showed that independent of group, the magnitude of arch reduction from transverse arch to aortic isthmus, correlated directly with the amount of $E_{L}$ across the entire measured aorta. Notably, there was not a significant association between palliation stage and $E_{L}$, suggesting that initial arch geometry-independent of arch growth-heavily influences flow dynamics.

The clinical importance of these findings is rooted in the fact that delaying Fontan failure is among the most difficult challenges faced by clinicians treating patients with singleventricle physiology. Intuitively, it is reasonable to assume that optimal ventricular-aortic coupling and improved right ventricle efficiency would perhaps help delay Fontan failure. The current study is among the first to show that suboptimal arch reconstruction leads to flow related $E_{L}$ and diminished right ventricle power. As such, it provides a pathway to improve right ventricle efficiency and potentially improve long-term survival for patients with HLHS.

\section{References}

1. Schäfer M, Di Maria MV, Jaggers J, Stone ML, Ivy DD, Barker AJ, et al. High-degree Norwood neoaortic tapering is associated with abnormal flow conduction and elevated flow-mediated energy loss. J Thorac Cardiovasc Surg. 2021;162: 1791-804.

2. Norwood WI, Lang P, Hansen DD. Physiologic repair of aortic atresia-hypoplastic left heart syndrome. $N$ Engl J Med. 1983;308:23-6.

3. Karamlou T, Najm HK. Evolution of care pathways for babies with hypoplastic left heart syndrome: integrating mechanistic and clinical process investigation, standardization, and collaborative study. J Thorac Dis. 2020;12:1174-83.

4. Wilder TJ, McCrindle BW, Phillips AB, Blackstone EH, Rajeswaran J, Williams WG, et al. Survival and right ventricular performance for matched children after stage-1 Norwood: modified Blalock-Taussig shunt versus rightventricle-to-pulmonary-artery conduit. J Thorac Cardiovasc Surg. 2015;150: 1440-50.

5. Ohye RG, Sleeper LA, Mahony L, Newburger JW, Pearson GD, Lu M, et al. Comparison of shunt types in the Norwood procedure for single-ventricle lesions. $N$ Engl J Med. 2010;362:1980-92.

6. Gewillig M, Goldberg DJ. Failure of the Fontan circulation. Heart Fail Clin. 2014; 10:105-16.

7. Gewillig M, Brown SC, Eyskens B, Heying R, Ganame J, Budts W, et al. The Fontan circulation: who controls cardiac output? Interact Cardiovasc Thorac Surg. 2010;10:428-33.

8. Egbe AC, Connolly HM, Miranda WR, Ammash NM, Hagler DJ, Veldtman GR, et al. Hemodynamics of Fontan failure: the role of pulmonary vascular disease. Circ Heart Fail. 2017;10:e004515.

9. Rychik J, Atz AM, Celermajer DS, Deal BJ, Gatzoulis MA, Gewillig MH, et al. Evaluation and management of the child and adult with Fontan circulation: a scientific statement from the American Heart Association. Circulation. 2019. CIR0000000000000696. 